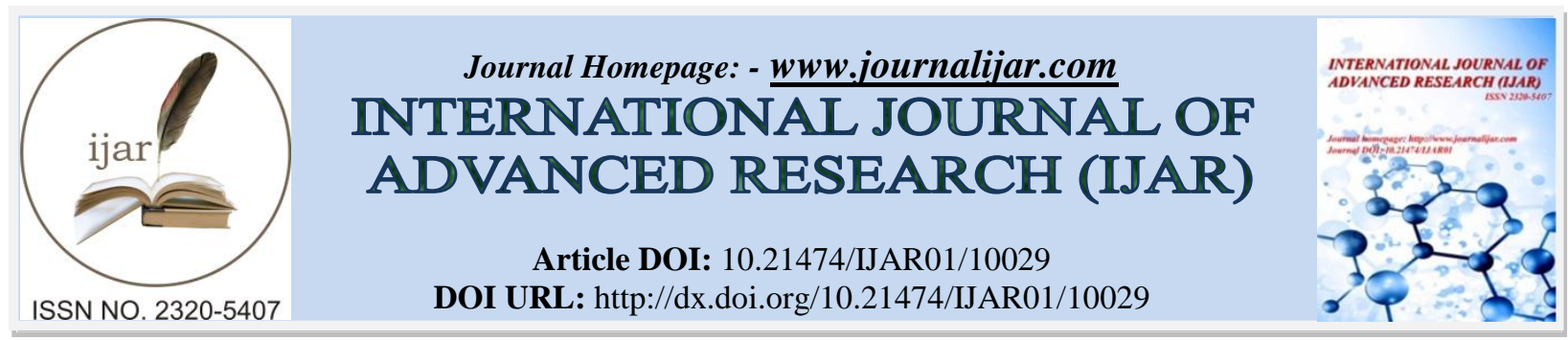

RESEARCH ARTICLE

\title{
A CLINICAL STUDY ON THE EFFECT OF VATAGAJANKUSHA RASA IN GRIDHRASI.
}

\section{Dr. Jibi Varghese T. ${ }^{1}$, Dr. Jonah S. ${ }^{2}$, Dr. Vaishali Deshpande ${ }^{3}$ and Manna Mathew ${ }^{4}$.}

1. Ph.D. Scholar, Department of Kayachikitsa, Parul Institute of Ayurveda, Parul University, Vadodara.

2. Professor, Department of Kayachikitsa,Rajiv Gandhi Ayurveda Medical College, Mahe.

3. Professor, Department of Kayachikitsa, Parul Institute of Ayurveda, Parul University.

4. P.G. Second Year, Department of Dravyaguna, Dr.D.Y.Patil College of Ayurveda \&Research Centre, PimpriPune.

\section{Manuscript Info}

…......................

Manuscript History

Received: 10 September 2019

Final Accepted: 12 October 2019

Published: November 2019

Key words:-

Gridhrasi; Sciatica; Vatagajankusha

Rasa.

\section{Abstract}

Low backache is the fifth most common cause for all physician visits. The last few decades have shown that social and economical factors have great influence on the health. The present day life style and nature of work may be one of the causes for this malady. Gridhrasi is one such disease which is characterized by low backache with radiating pain up to the heel and causing the patient to walk like Gridhra, therefore been termed as Gridhrasi, which can be compared to that of Sciatica of contemporary Sciences ${ }^{1,2}$. Most of them neglect the preliminary stage of pain and refuse treatment but later, in advanced condition of the disease it becomes a must for them to seek medical advice. In allopathy, initially medications are advised and later patient may be suggested for surgical intervention. The cost is also not affordable by common man. So, a medicine, which relieves the pain, improves and restores functional ability, is the need for study.

This is a Open label Comparative clinical study with pre-test and posttest design where in 40 patients suffering from Gridhrasi of either gender between the age group of 16 to 60 years were randomly selected and grouped into Group A and Group B. The patients in Group A were treated with Vatagajankusha Rasa $125 \mathrm{mg}$ bd with lukewarm water as Anupana Group B was given with Vatagajankusha Rasa $125 \mathrm{mg}$ bd with Manjistha kwatha $50 \mathrm{ml}$ and Pippali choorna $3 \mathrm{gm}$ bd as Anupana for 7 days. Results obtained were analyzed for the statistical significance by adapting paired and unpaired ' $t$ ' test. The study revealed that Group B ie, Vatagajankusha Rasa with the Anupana of Manjistha kwatha and Pippali choorna was found to be more effective in bringing symptomatic relief and improving functional ability in the patients of Gridhrasi.

Copy Right, IJAR, 2019,. All rights reserved.

\section{Introduction:-}

Man is unique among his vertebrate cousins in stance of his upright stature. Other primates may enjoy the canopy of the tropical forest, sometimes climbing, sometimes semi-upright, but man alone is comfortable and confident with

Corresponding Author:-Dr. Jibi Varghese T.

Address:-Ph.D. Scholar, Department of Kayachikitsa, Parul Institute of Ayurveda, Parul University, 
the upright bipedal posture. Spinal anatomy is a remarkable combination of strong bones, flexible ligaments and tendons, large muscles and highly sensitive nerves. The harmony of all these structures enables man to run with the pace of time. Man is taking the juxtaposition of strength, structure and flexibility of the spine for granted in everyday life.

Changing of life style of modern human being has created several disharmonies in his biological system. As the advancement of busy professional and social life, improper sitting posture in offices, factories, continuous and overexertion, jerky movements during traveling and sports - all these factors create undue pressure to the spinal cord and play an important role in producing low backache and pain radiating down the leg. Likewise, progressive disorders affecting the pelvis and nearer structures are also precipitating this condition. In this way, this disease is now becoming a significant threat to the working population. The disorder apparently seems to be non-serious but it cripples the patient and results in apprehension of social responsibilities and it also leads to draining of National Resource due to work hours lost, resulting into diminished production

Ayurveda had identified this problem long back and named it 'Gridhrasi'. Gridhrasi is considered as Shoola Pradhana Vatavyadhi. The cardinal sign and symptoms of Gridhrasi ${ }^{3}$ are Ruka (Pain), Toda (Pricking sensation), Stambha (Stiffness) and Muhurspandana (Involuntary Movements) in the Sphik, Kati, Uru, Janu, Jangha and Pada in order and Sakthishepan-nigraha i.e. restricted lifting of the legs.

\section{Materials And Methods:-}

\section{Aim}

1. To evaluate the therapeutic efficacy of Vatagajankusha Rasa in bringing symptomatic Gridhrasi

2. To evaluate the therapeutic efficacy of Vatagajankusha Rasa and its Anupana in bringing relief in patients of Gridhrasi

3. To compare the results of both the groups.

\section{Source of data}

The patients who attended the OPD and IPD of S.D.M. Ayurveda Hospital, Udupi having the complaints of Low backache radiating to leg were screened. Among them 40 patients fulfilling the inclusion criteria of the present study were taken. A detailed history taking and physical examinations were carried out in these patients. Relevant data along with the elaborate assessment of Pain, Neurological deficit, Functional Ability \& Functional Disability was registered in the designed case proforma.

\section{Inclusion Criteria}

The patients were taken for the present study as per the following inclusion criteria.

1. Patients with pratyatma lakshana of Gridhrasi.

2. Patients between the age group of 16 to 60 years.

3. Patients having positive physical signs of radicular pain/ Sciatica

\section{Exclusion Criteria}

The patients suffering from Gridhrasi caused due to the following were excluded from the study.

1. Neoplastic conditions of spine.

2. Trauma of spine

3. Infections of spine.

\section{Investigations}

Routine hematological investigations along with radiological investigations were carried out when ever found necessary.

\section{Design}

It is a single blind clinical study with pre test and post test design were in 40 patients diagnosed to have Gridhrasi fulfilling all the criteria for the study were selected randomly and was placed in a two groups A \& B. 


\section{Intervention}

The patients of Group A were treated with oral administration of Vatagajankusha Rasa 1 Bd with warm water and Group B were treated with Vatagajankusha Rasa with anupana as Manjishtha kwatha 50 ml and Pippali choorna 3 gram BD for the duration of 7 days.

\section{Assessment criteria}

Assessment was done initially before intervention of medicine and there after weekly for a period of 28 days. In the follow up period of 28days, the patients were assessed once in 7 days. Assessment was done by using the below mentioned

\section{Scoring method.}

Stambha (Stiffness):

1. No stiffness

$-0$

2. Mild stiffness

3. Moderate stiffness

$-1$

4. Severe stiffness

$-2$

$-3$

\section{Ruk (Pain):}

1. No pain

2. Painful, walks without limping

3. Painful, walks with limping but without support -2

4. Painful, can walk only with support

5. Painful, unable to walk

Toda (Pricking Sensation):

1. No pricking sensation

2. Mild pricking sensation

3. Moderate pricking sensation

4. Severe pricking sensation

\section{Spandana (Twitchings):}

1. No twitching

2. Mild twitching

3. Moderate twitching

4. Severe twitching

- 0

$-1$

$-2$

$-3$

Aruci (Anorexia):

1. No anorexia

2. Mild anorexia

3. Moderate anorexia

4. Severe anorexia

- 0

$-1$

$-2$

$-3$

Tandra (Stupor):

1. No stupor

2. Mild stupor

3. Moderate stupor

4. Severe stupor

- 0

$-1$

$-2$

$-3$

Gaurava (Heaviness):

1. No heaviness

2. Mild heaviness

3. Moderate heaviness

4. Severe heaviness

- 0

$-1$

$-2$

$-3$

Assessment of Pain - Greenough and Fraser scoring method 
Assessment of Neurological Deficit

Assessment of Functinal Ability Sugarbaker and Barofsky Clinical Mobility scale

Functional Disability Oswestry Disability assessment Questionaire.

\section{Schematic Representation Of Samprapti}

Samprapti Ghataka -

1. Nidana : Vataprakopaka nidana

2. Dosha : Vata - Apana, Vyana vayu and Kapha.

3. Dushya : Sira, Snayu. Kandara, Asthisandhi,

4. Agni : Jatharagni

5. Ama : Nirama(vata pradhana) Ama (kapha pradhana)

6. Udbhavasthana : Pakwashaya

7. Sancharasthana : Sarvashareera

8. Srotas : Vatavaha ( Sanjyavaha and Chestavaha)

9. Srotodushti : Sanga

10. Rogamarga : Madhyama

11. Vyaktasthana : Sphik, Kati, Prishtha, Uru, Janu, Jangha, Pada.

12. Bheda : Vataja and Vatakaphaja

13. Swabhava : Chirakari

\section{Drug Review}

In the present clinical trial Vatagajankusha Rasa ${ }^{4}$ mentioned Rasendra Saar Samgraha administered for the patients of Gridhrasi. The details of the ingredients of these medicinal combinations are detailed below.

\section{Vatagajankusha Rasa}

1. Rasasindhura

2. Lohabhasma

3. Swarnamakshika bhasma

4. Shuddha Gandhaka

5. Shuddha Hartala

6. Haritaki choorna (Terminalia Chebula)

7. Kakadsringi choorna (Pistacia integerrima)

8. Shuddha Vatsanabha choorna (Aconitum ferox)

9. Shunthi choorna (Zingiber officinale)

10. Pippali choorna (Piper longum)

11. Maricha choorna (Piper nigrum)

12. Agnimantha choorna (Clerodendrum phlomidis)

13. Shuddha Tankana

Bhavana Dravyas :

Nirgundi and Mundi Swarasa

\section{Method of preparation :}

Firstly Rasasindhura is to be pulverized, later mixing in with all the Shuddha Bhasmas and drugs and it should be triturated with Mundi swarasa and Nirgundi swarasa. Then this is to be made into the form of vati and dried up in shade and preserved well in a glass bottle or a air tight tin.

$\begin{array}{ll}\text { 1 part } & \\ 1 \text { part } & \\ & \text { 1 part } \\ 1 \text { part } & \\ & \begin{array}{l}\text { 1part } \\ \text { 1 part }\end{array} \\ \text { 1 part } & \\ \text { 1 part } & \\ \text { 1 part } & \\ & \text { 1 part } \\ & \text { 1 part } \\ \text { 1 part } & \\ 1 \text { part } & \end{array}$


Table No1:-Showing Drugs in Vatagajankusha Rasa and its Rasapanchaka

\begin{tabular}{|l|c|c|c|c|c|}
\hline \multicolumn{1}{|c|}{ Dravya } & Rasa & Guna & Virya & Vipaka & Karma \\
\hline Rasasindhura & - & - & - & - & Tridoshahara \\
\hline Loha bhasma & Tikta kashaya & Ruksha,guru & Sheeta & Madhura & Kaphaghna \\
\hline Swrnamakshika & Madhura. & Laghu & Sheeta & Katu & Tridoshahara \\
\hline Gandhaka & Madhura. & Ruksha & Ushna & Katu & Kaphavataghna \\
\hline Tankana & Katu & Ruksha tikshna & Ushna & Katu & Kaphahara \\
\hline Hartala & Katu & Snigdha & Ushna & & Kaphavatahara \\
\hline Hareetaki & Pancha rasa & Laghu ruksha & Ushna & Madhura & Tridoshahara \\
\hline Karkatashringi & Kashaya, tikta & Laghu ruksha & Ushna & Katu & Kaphavatahara \\
\hline Vatsanabha & Madhura & Laghu tikshna & Ushna & Madhura & Vata sleshmahara \\
\hline Shunthi & Katu & Snigdha & Ushna & Madhura & Kaphavatahara \\
\hline Pippali & Katu & Snigdha laghu & Ushna & Katu & Vatasleshmahara \\
\hline Agnimantha & Tikta katu kashaya & Ruksha laghu & Ushna & Katu & Kaphavatahara \\
\hline Mundi & Tikta katu & Laghu ruksha & Ushna & Katu & Tridoshahara \\
\hline Nirgundi & Katu tikta & Laghu ruksha & Ushna & Katu & Vata kaphahara \\
\hline Manjistha & Madhura, tikta & Guru , ruksha & Ushna & Katu & Kaphapittahara \\
\hline
\end{tabular}

\section{Observations}

The distribution of patients in both the groups showed maximum number of patients having Vatapitta prakruti and in the working age group (31-45yrs). Female patients showed more prevalence who were housewifes. Habitat ie the Urban -Rural ratio in the present study didnt show marked significance, even though rural ratio was found to have a upperhand. Sedentary Nature of work with Madhyam Sara had more prevalence rate in the present study.

\section{Results of group ' $a$ ' and group ' $b$ ' :}

\begin{tabular}{|l|l|c|c|}
\hline $\begin{array}{l}\text { Sr. } \\
\text { No. }\end{array}$ & Effect of Treatment on Symptoms & $\begin{array}{l}\text { Group A ( 20 patients) } \\
\text { Standard Deviation ( S.D.) }\end{array}$ & $\begin{array}{l}\text { Group B ( 20 patients) } \\
\text { Standard Deviation( S.D.) }\end{array}$ \\
\hline 1. & Effect of Stambha & 0.308 & 0.324 \\
\hline 2. & Effect on Ruk & 0.410 & 0.587 \\
\hline 3. & Effect on Toda & 0.510 & 0.523 \\
\hline 4. & Effect on Grahana & 0.489 & 0.550 \\
\hline 5. & Effect on Spandana & 0.513 & 0.587 \\
\hline 6. & Effect on Aruchi & 0.224 & 0.550 \\
\hline 7. & Effect on Gaurava & 0.224 & 0.773 \\
\hline 8. & Effect on Pain & 2.505 & 5.871 \\
\hline 9. & Effect on Neurological deficit & 3.663 & 6.708 \\
\hline 10. & Effect on Functional ability & 3.088 & 4.494 \\
\hline 11. & Effect on Functional disability & 2.707 & 3.774 \\
\hline
\end{tabular}

Table No 2:-Showing the Overall Effect of Treatment

\begin{tabular}{|l|c|c|c|c|}
\hline \multicolumn{1}{|c|}{ Effect } & $\begin{array}{c}\text { No. of patients } \\
\text { Group A }\end{array}$ & $\begin{array}{c}\text { Percentage } \\
\text { \% }\end{array}$ & $\begin{array}{c}\text { No. of patients } \\
\text { Group B }\end{array}$ & $\begin{array}{c}\text { Percentage } \\
\text { \% }\end{array}$ \\
\hline Cured & 5 & 25 & 8 & 40 \\
\hline Best improvement & 5 & 25 & 5 & 25 \\
\hline Mod. improvement & 6 & 30 & 5 & 25 \\
\hline Mild improvement & 4 & 20 & 2 & 10 \\
\hline Unchanged & 0 & 0 & 0 & 0 \\
\hline
\end{tabular}


Graph No 1:-Showing the Overall Effect of Treatment

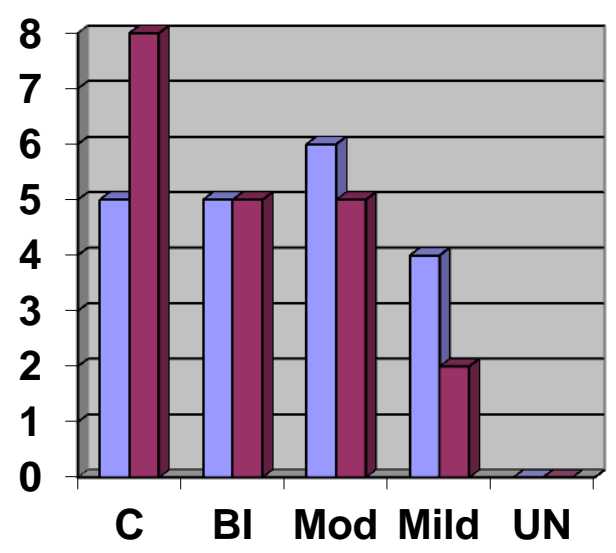

\section{$\square$ Group A $\square$ Group B}

\section{Conclusion:-}

Vatagajankusha Rasa is a Herbo-mineral combination with specific ingredients like Rasasindhura, Loha bhasma, Swarna makshika, Gandhaka, Hartala, Vatsanabha, Tankana, Trikatu etc with the bhavana or fortification with Nirgundi and Mundi which makes the drug more potent against vata and kapha disorders. All of the drugs are having tridoshaghna or vatakaphahara qualities with ushna veerya which shows its action on both variants of Gridhrasi. Vatagajankusha Rasa when given with anupana of Manjishta Kwatha and Pippali choorna adds on to the benefit. It acts as a good amapachaka and dipana where it gives good result in vatakaphaja Gridrasi in symptoms of aruchi, tandra and gaurava.

Here in this study Vatagajankusha Rasa with luke warm water as anupana was given in Group A. The overall effect of the medication revealed $25 \%$ patients got cured as well as got best improvement in the symptoms respectively. $30 \%$ got moderate relief while $20 \%$ got mild relief from the symptoms. The second Group B, which was tried with Vatagajankusha Rasa and anupana of Manjishta kwatha and Pippali choorna, nearly 40\% of the patients got cured and $25 \%$ each got best and moderate relief from the symptomolgy. $10 \%$ of the patients got mild improvement. Thus this present clinical study proved Vatagajankusha Rasa is effective in Gridhrasi.Though on comparing the efficacy of both the groups showed insignificant results yet; Group B had good results compared to that of Group A since it had an added effect of the anupana yoga.

\section{References:-}

1. French Index of Differential Diagnosis, 14th edition, edited by Mark Kinirons and Harald Ellis, 2005, Pp 831, page 378.

2. Harrison's Principles of Internal Medicine- Volume I edited by Kasper, Braunwald, Fauci, Hauser, Longo, Jameson, 16th edition pp1299, pg no. 144

3. Agnivesha, Charaka samhitha, revised by Charaka and Dridabala with Ayurveda dipika commentary of Chakrapanidatta, edited by Yadavji Trikamji Acharya, Chikitsasthana 28th Chapter, Sloka No.56, 5th edition2007, Chaukambha Sanskrit sansthan, Pp.738, Page no. 619

4. Sri Gopal Krishna, Rasendra Saar Sangraha, Commentary by Vaidya Satyarath Prakash, Vatavyadhi Chikitsa prakaran, $4^{\text {th }}-8^{\text {th }}$ Verse, Krishnadas Academy, Varanasi, pp742- pg no.490 